\title{
Lead Affects Vitamin D Metabolism in Rats
}

\author{
Abdur Rahman ${ }^{1, *}$, Ameena A. Al-Awadi ${ }^{1}$ (i) and Khalid M. Khan ${ }^{2}$ \\ 1 Department of Food Science and Nutrition, College of Life Sciences, Kuwait University, P.O. Box 5969, \\ Safat 13060, Kuwait; alawadi.cfw@gmail.com \\ 2 Department of Anatomy, Faculty of Medicine, Kuwait University, P.O. Box 24923, Safat 13110, Kuwait; \\ khalid.khan@hsc.edu.kw \\ * Correspondence: abdurrahman.ahmad@ku.edu.kw; Tel.: +965-2463-3055; Fax: +965-2251-3929
}

Received: 4 January 2018; Accepted: 22 February 2018; Published: 26 February 2018

\begin{abstract}
A negative association between blood lead and vitamin D concentrations has been reported, however, experimental data on the effect of lead $(\mathrm{Pb})$ on vitamin $\mathrm{D}$ metabolism is scarce. We investigated the effects of $\mathrm{Pb}$ on serum vitamin $\mathrm{D}$ metabolites, vitamin $\mathrm{D}$ activating enzymes and vitamin D receptor (VDR) in rats. Newborn Wistar rat pups were exposed to $0.2 \% \mathrm{~Pb}$-acetate via their dams' drinking water from post-natal day (PND) 1 to 21 and directly in drinking water until PND30. Serum 25-hydroxyvitamin D was analyzed with LC-MS/MS and 1,25-dihydroxyvitamin D with an immunoassay. Tissue expression of vitamin D activating enzymes and VDR were measured by Western blot and immunohistochemistry. Serum 25-hydroxyvitamin D was significantly decreased at both PND21 and PND30, whereas 1,25-dihydroxyvitamin D was decreased $(p<0.05)$ only at $\mathrm{PND} 21$ in the $\mathrm{Pb}$-exposed rats. Expression of renal 1- $\alpha$-hydroxylase was decreased by $\mathrm{Pb}$ only at PND21 $(p<0.05)$ but the brain 1- $\alpha$-hydroxylase was not affected. Hepatic 25-hydroxylase expression was significantly decreased at PND21 but significantly increased at PND30 by Pb exposure. VDR expression in the brain was increased at both PND21 and PND30 $(p<0.05)$. These results suggest that $\mathrm{Pb}$ interferes with vitamin $\mathrm{D}$ metabolism by affecting the expression of its metabolizing enzymes.
\end{abstract}

Keywords: lead; vitamin D; 25-hydroxy vitamin D; 1,25-dihydroxy vitamin D; 25-hydroxylase; 1- $\alpha$-hydroxylase; vitamin D receptor; rats

\section{Introduction}

Vitamin D has been implicated in several physiological functions that extend beyond its classical effects on bone mineralization [1]. One of the recent emerging roles of vitamin D is its involvement in maintaining the health and development of both fetal and adult brain [2,3]. Vitamin D receptors (VDR) and metabolizing enzymes (hepatic 25 -hydroxylase and renal $1 \alpha$-hydroxylase) have been found in several human brain areas [4] which are involved in planning, processing and formation of new memories $[4,5]$.

Lead $(\mathrm{Pb})$ is a known neurotoxic heavy metal [6-8] that is ubiquitously present in our environment and is still being used in various industries $[9,10]$. With the development of modern building structures, transportation and industry, Vitamin D deficiency (VDD) as well as $\mathrm{Pb}$ poisoning have become more prevalent at global level, resulting in serious problems especially among children [11-15]. The reported neurological deficits from childhood $\mathrm{Pb}$ toxicity [7] have led to the progressive decline in the definition of $\mathrm{Pb}$ poisoning reference level from $60 \mu \mathrm{g} / \mathrm{dL}$ to $5 \mu \mathrm{g} / \mathrm{dL}[16,17]$. Yet, there is no safe level of $\mathrm{Pb}$ exposure for children $[18,19]$.

It has been suggested that high $\mathrm{Pb}$ exposure is one of the potential risk factor of VDD [20,21]. Studies of children with high $\mathrm{Pb}$ exposure demonstrated a significant negative association between 1,25-dihydroxyvitamin $\mathrm{D}\left[1,25(\mathrm{OH})_{2} \mathrm{D}\right]$ concentration and blood Pb level (BPbL) [22-25]. Children whose BPbLs were in the range of $33-55 \mu \mathrm{g} / \mathrm{dL}$ showed a significant reduction in serum 
$1,25(\mathrm{OH})_{2} \mathrm{D}$ concentration. The decrease in serum $1,25(\mathrm{OH})_{2} \mathrm{D}$ was even more pronounced in children with $\mathrm{BPbL}$ of $>62 \mu \mathrm{g} / \mathrm{dL}$, suggesting a dose-dependent effect of $\mathrm{Pb}$ on vitamin $\mathrm{D}$ status [24]. Data from animal studies have shown that $\mathrm{Pb}$ ingestion decreased serum concentration of $1,25(\mathrm{OH})_{2} \mathrm{D}$ and blocked vitamin D-dependent intestinal calcium transport in rats [26]. High $\mathrm{BPbL}$ has been suggested to cause disruption of the renal hydroxylation of 25 -hydroxyvitamin $\mathrm{D}[25(\mathrm{OH}) \mathrm{D}]$ by 1 - $\alpha$-hydroxylase to produce the active form of vitamin $\mathrm{D} ; 1,25(\mathrm{OH})_{2} \mathrm{D}$ [27]. Consequently, reduction of serum $1,25(\mathrm{OH})_{2} \mathrm{D}$ synthesis induced by $\mathrm{Pb}$ toxicity is accompanied with reduced calcium levels and increased serum parathyroid hormone (PTH) levels. Thus, $\mathrm{Pb}$ interferes with various vitamin $\mathrm{D}$ functions involved in calcium balance and metabolism in various tissues and organs [28-31]. However, the mechanism(s) of these effects have not been elucidated. This study was thus conducted to investigate the effect of $\mathrm{Pb}$ exposure on (1) serum vitamin $\mathrm{D}$ metabolites levels; $25(\mathrm{OH}) \mathrm{D}$ and $1,25(\mathrm{OH})_{2} \mathrm{D} ;(2)$ the expression of vitamin D metabolizing enzymes; 25-hydroxylase in the liver and 1- $\alpha$-hydroxylase in the kidneys and brain and (3) the expression of VDR in brain of Wistar rat pups exposed to Pb during their early postnatal life.

\section{Materials and Methods}

\subsection{Pb Exposure Protocol}

Wistar rats were used in this study. Animal exposure and handling was according to the approved protocol of Institutional Animal Care and Use Committee of Kuwait University. Animals were housed at constant temperature $\left(21 \pm 2{ }^{\circ} \mathrm{C}\right)$ and a relative humidity, under a 12-h light/dark cycle (lights on from 700 to $1900 \mathrm{~h}$ ) with free access to food and water. Ten females were mated; eight of them became pregnant. Pregnancy was confirmed with swab test of vaginal smear. At birth pups were randomly culled to 7-8 per dam. Pups in the experimental group were exposed to $0.2 \% \mathrm{~Pb}$ acetate via their dams' drinking water from postnatal day (PND) 1 to PND21 and directly through drinking water until $\mathrm{PND30.} \mathrm{The} \mathrm{control} \mathrm{group} \mathrm{were} \mathrm{given} \mathrm{regular} \mathrm{tap} \mathrm{water.} \mathrm{Pb}$ concentration in the tap water was below the detection limit of the assay. The number of pups in the experimental (Pb-exposed) and control groups were 37 and 38, respectively.

\subsection{Collection of Blood and Tissue Samples}

Half of the pups from each group were euthanized with $\mathrm{CO}_{2}$, weighed and decapitated at PND21 and the rest at PND30. Blood was drawn from the right ventricle. $100 \mu \mathrm{L}$ whole blood was aliquoted and stored in the refrigerator $\left(\right.$ at $4{ }^{\circ} \mathrm{C}$ ) for $\mathrm{Pb}$ analysis. The remaining blood was centrifuged at $12,000 \times g$ for $15 \mathrm{~min}$ to obtain serum for vitamin D metabolites analysis. Serum samples were stored at $-80{ }^{\circ} \mathrm{C}$ until analysis. Samples were protected from light throughout processing and storage. Cerebral hemispheres, liver and kidneys were dissected out, weighed, frozen in liquid nitrogen and stored at $-80^{\circ} \mathrm{C}$ until analyses. At the end of the study, dams were euthanized with $\mathrm{CO}_{2}$.

\section{3. $\mathrm{Pb}$ Analysis}

$\mathrm{Pb}$ concentrations in the digested blood samples were quantified with inductively coupled plasma-optical emission spectrometer (ICP-OES). For digestion, whole blood samples (100 uL) were digested by overnight incubation in a mixture of $1 \mathrm{~mL}$ nitric acid (ultra-pure) and $1.5 \mathrm{~mL}$ perchloric acid, followed by heating (to $50^{\circ} \mathrm{C}$ ) for $30 \mathrm{~min}$ and boiling (at $90^{\circ} \mathrm{C}$ ) for $15 \mathrm{~min}$. While heating, nitric acid was added gradually to each sample, as needed until the solution turned clear. Nitric acid was evaporated under the fume hood and the dried residue was dissolved in $3 \mathrm{~mL}$ of deionized water. Five standards of $\mathrm{Pb}$ solutions were prepared with a range of $0,0.01,0.05,0.1 \mathrm{and} 0.5 \mathrm{mg} / \mathrm{L}$ from standard stock solution by dilution with deionized water.

The system used for $\mathrm{Pb}$ analysis was a computer-controlled sequential ICP-OES spectrometer covering a spectral wavelengths range of 160-800 nm (iCAP 6500 ICP-OES; Thermo Fisher Scientific Inc., Cambridge, UK) with $1 \mathrm{Kw}$ of RF Power, pump speed of $15 \mathrm{rpm}$ and gas flows of $1.5 \mathrm{~L} / \mathrm{min}$ for 
the plasma, $0.5 \mathrm{~L} / \mathrm{min}$ for the auxiliary flow and below $1 \mathrm{~L} / \mathrm{min}$ for the nebulizer pressure. A 60-s washing time was performed between each sample. A wavelength of 220.3 was used for Pb detection using the Optimize Source function of Thermo Scientific iTEVA Software (Cat. No. 849940030001 , Thermo Fisher Scientific Inc., Cambridge, UK).

\subsection{Vitamin D Metabolites Analysis}

Serum 25(OH)D was analyzed in CAP-accredited laboratory by liquid chromatography-tandem mass spectrometry (LC-MS/MS) as described by Al-Harbi et al. [32], using the commercially available kits from Chromsystems (Cat. \#2000/1000/F; Chromsystems Instruments \& Chemicals GmbH, Grafelfing, Germany) according to the manufacturer's instructions. Precision and accuracy of analysis were monitored by including control samples (MassCheck controls). The intra-assay and inter-assay CV were $3.7 \%$ and $6.0 \%$, respectively. Serum $1,25(\mathrm{OH})_{2} \mathrm{D}$ was analyzed by the commercially available Diasorin kit (Cat. \# 310981, DiaSorin Inc., Stillwater, MN, USA), using the LIASON, DiaSorin system.

\subsection{Western Blotting}

The expression of 25-hydroxylase, 1- $\alpha$-hydroxylase and VDR were analyzed by Western blot. Tissue samples were homogenized in RIPA buffer (50 mM Tris, pH 7.4, $150 \mathrm{mM} \mathrm{NaCl,} \mathrm{1 \%} \mathrm{NP-40,}$ $5 \mathrm{mM}$ EDTA, 0.5\% sodium deoxycholate, 0.1\% SDS, $50 \mathrm{nM} \mathrm{NaF}$ ) and protease inhibitor cocktail (Roche Diagnostic, Castle Hill, NSW, Australia). Concentration of protein in tissue samples were measured by Bradford method. Samples were stored at $-80{ }^{\circ} \mathrm{C}$ until used.

An aliquot of tissue lysate (20 $\mu$ g protein) was resolved by electrophoresis on $10 \%$ SDS-PAGE (NuPAGE, Invitrogen, Carlsbad, CA, USA). Proteins were transferred onto PVDF membranes and the membranes were blocked with $5 \%$ powdered milk in TBS for $1 \mathrm{~h}$ and incubated with primary antibodies (Table 1 ) overnight at $4{ }^{\circ} \mathrm{C}$. The dilution factor for all the primary antibodies was 1:1000. The membranes were washed with TBS-Tween $3 \times(5$ min each $)$ and $2 \times$ with TBS only. Afterwards membranes were incubated with the HPR-conjugated secondary antibody for $2 \mathrm{~h}$ at room temperature, washed as above and developed using ECL kit (GE Healthcare Life Sciences, Westborough, MA, USA). Beta-actin was used as loading control. Blots were scanned and quantification of band density was measured by using Syngene gene tools software (Gene Tools Image Analysis, Philomath, OR, USA).

Table 1. List of Primary Antibodies.

\begin{tabular}{ccccc}
\hline Primary Antibody & Tissue & Colonality & Dilution & Source \\
\hline $\begin{array}{c}\text { Anti-CYP27B1 } \\
(1-\alpha \text {-hydroxylase })\end{array}$ & Brain, kidney & polyclonal & $\begin{array}{c}1: 1000 \text { for WB } \\
1: 100 \text { for IHC }\end{array}$ & $\begin{array}{c}\text { USCN Life Sciences Inc., } \\
\text { Wuhan, China }\end{array}$ \\
\hline $\begin{array}{c}\text { Anti-CYP27A1 } \\
(25-\text {-hydroxylase })\end{array}$ & Liver & monoclonal & $\begin{array}{c}1: 1000 \text { for WB } \\
1: 100 \text { for IHC }\end{array}$ & $\begin{array}{c}\text { Abcam, Cambridge, } \\
\text { MA, USA }\end{array}$ \\
\hline VDR antibody & Brain & monoclonal & $1: 1000$ for WB and IHC & $\begin{array}{c}\text { Aviva systems biology, } \\
\text { San Diego, CA, USA }\end{array}$ \\
\hline Anti- $\beta$-actin & All the above tissues & monoclonal & $1: 2000$ & $\begin{array}{c}\text { Sigma-Aldrich, St. Louis, } \\
\text { MO, USA }\end{array}$ \\
\hline
\end{tabular}

\subsection{Immunohistochemistry}

The specificity of antibodies for 25-Hydroxylase, 1- $\alpha$-hydroxylase and VDR was tested by Western blot before immunohistochemistry. Animals were euthanized with $\mathrm{CO}_{2}$ and perfused transcardially with normal saline followed by a fixative that consisted of $4 \%$ paraformaldehyde and $0.1 \%$ glutaraldehyde in $100 \mathrm{mM}$ phosphate buffer, $\mathrm{pH} 7.4$ at $4{ }^{\circ} \mathrm{C}$. Brain, liver and kidneys were collected and transferred to a cold fixative for $24 \mathrm{~h}$ at $4{ }^{\circ} \mathrm{C}$. Tissues were washed overnight in cold phosphate buffer, then dehydrated in graded ethanol, cleared in xylene and embedded in paraffin. Sections $(8 \mu \mathrm{m})$ were cut using rotary microtome and two sections were mounted on each slide. 
Sections were de-paraffinized and rehydrated at room temperature. All sections were quenched for free aldehyde groups and endogenous peroxidase activity with $3 \% \mathrm{H}_{2} \mathrm{O}_{2}$ in water and $0.1 \%$ sodium borohydride and $50 \mathrm{mM}$ glycine in PBS; respectively. Sections were washed with PBS three times and incubated in $2 \%$ normal serum for $1 \mathrm{~h}$ at room temperature $\left(25^{\circ} \mathrm{C}\right)$ to block nonspecific binding and kept overnight (for $12-16 \mathrm{~h}$ at $4{ }^{\circ} \mathrm{C}$ ) in primary antibody (Table 1). Next day, sections were washed with PBS three times (5 min each) and incubated in biotin-conjugated secondary antibody for 90 min followed by incubation in streptavidin peroxidase solution for $30 \mathrm{~min}$. Reactive sites were visualized with diaminobenzidine as a chromogen. One section on each slide was counterstained with hematoxylin prior to mounting. Sections that were incubated in normal serum (instead of the primary antibody) served as negative controls.

\subsection{Statistical Analysis}

Means of the data for each group (Pb-exposed and control) were compared by Student $t$-test for two independent samples with unequal variances. The association of blood $\mathrm{Pb}$ with $25(\mathrm{OH}) \mathrm{D}$ and $1,25(\mathrm{OH})_{2} \mathrm{D}$ was evaluated by linear regression analysis. Data were presented, as mean $\pm \mathrm{SD}$ and the significance level of difference was set at $p<0.05$. Data were analyzed by SPSS for Windows version 23 (SPSS Inc., Chicago, IL, USA).

\section{Results}

$\mathrm{Pb}$ exposure did not affect the body weight of pups either at PND21 or PND30. Weights of brain, liver and kidneys were also not significantly affected $(p>0.05)$ by Pb-exposure either at PND21 or PND30 (Table 2). Mean BPbL in the Pb-exposed rats was significantly increased $(p<0.0001)$ at both PND21 and PND30 (12.3 and $22.7 \mu \mathrm{g} / \mathrm{dL}$; respectively) compared to the respective control groups (2.2 and $3.3 \mu \mathrm{g} / \mathrm{dL}$ at PND21 and PND30, respectively) (Table 3).

Table 2. Mean $( \pm \mathrm{SD})$ body and tissue weight $(\mathrm{g})$ of control and Pb-exposed Wistar rat pups at PND21 and PND30.

\begin{tabular}{ccccc}
\hline & \multicolumn{2}{c}{ PND21 } & \multicolumn{2}{c}{ PND30 } \\
\cline { 2 - 5 } & $\begin{array}{c}\text { Control } \\
(\boldsymbol{n}=\mathbf{2 0})\end{array}$ & $\begin{array}{c}\text { Pb-Exposed } \\
(\boldsymbol{n}=\mathbf{2 0})\end{array}$ & $\begin{array}{c}\text { Control } \\
(\boldsymbol{n}=\mathbf{1 9 )})\end{array}$ & $\begin{array}{c}\text { Pb-Exposed } \\
(\boldsymbol{n}=\mathbf{1 9})\end{array}$ \\
\hline Body weight & $35.0 \pm 3.2$ & $33.0 \pm 7.8$ & $71.1 \pm 7.1$ & $71.6 \pm 13.6$ \\
Brain weight & $1.3 \pm 0.1$ & $1.3 \pm 0.1$ & $1.4 \pm 0.2$ & $1.3 \pm 0.2$ \\
Liver weight & $1.2 \pm 0.2$ & $1.2 \pm 0.3$ & $1.9 \pm 0.2$ & $1.8 \pm 0.3$ \\
Kidney weight & $0.4 \pm 0.1$ & $0.4 \pm 0.1$ & $0.8 \pm 0.1$ & $0.9 \pm 0.2$ \\
\hline
\end{tabular}

SD: standard deviation; PND: postnatal day.

Table 3. Blood lead and serum vitamin D metabolites (Mean \pm SD) in control and Pb-exposed Wistar rat pups at PND21 and PND30.

\begin{tabular}{ccccc}
\hline & \multicolumn{2}{c}{ PND21 } & \multicolumn{2}{c}{ PND30 } \\
\cline { 2 - 5 } & $\begin{array}{c}\text { Control } \\
(\boldsymbol{n}=\mathbf{1 9 )})\end{array}$ & $\begin{array}{c}\text { Pb-Exposed } \\
(\boldsymbol{n}=\mathbf{2 0})\end{array}$ & $\begin{array}{c}\text { Control } \\
(\boldsymbol{n}=\mathbf{1 9 )})\end{array}$ & $\begin{array}{c}\text { Pb-Exposed } \\
(\boldsymbol{n}=\mathbf{2 0})\end{array}$ \\
\hline $\mathrm{Pb}(\mu \mathrm{g} / \mathrm{dL})$ & $2.2 \pm 0.7$ & $12.4 \pm 3.3^{* *}$ & $3.3 \pm 1.7$ & $22.7 \pm 6.0^{* *}$ \\
$25(\mathrm{OH}) \mathrm{D}(\mathrm{nmol} / \mathrm{L})$ & $32.2 \pm 7.5$ & $23.3 \pm 5.7^{*}$ & $32.2 \pm 6.3$ & $27.0 \pm 6.4^{*}$ \\
$1,25(\mathrm{OH})_{2} \mathrm{D}(\mathrm{pmol} / \mathrm{L})$ & $428.8 \pm 132.8$ & $361.5 \pm 83.6^{*}$ & $416.9 \pm 129.1$ & $379.7 \pm 108.1$ \\
\hline
\end{tabular}

* Significantly different from respective control $(p<0.05)$. ** Significantly different from respective control $(p<0.000001)$.

\subsection{Effect of Pb Exposure on Serum Vitamin D Metabolites}

The serum concentrations of $25(\mathrm{OH}) \mathrm{D}$ and $1,25(\mathrm{OH})_{2} \mathrm{D}$ are shown in Table 3 . No significant differences in either $25(\mathrm{OH}) \mathrm{D}$ or $1,25(\mathrm{OH})_{2} \mathrm{D}$ were found between pups at the two age groups (PND21 
and PND30) in both control and Pb-exposed animals. At both PND21 and PND30, Pb exposure significantly decreased serum 25(OH)D compared to the control group $(p=0.0001$ and $p=0.01$, for PND21 and PND30, respectively). Serum $1,25(\mathrm{OH})_{2} \mathrm{D}$ was decreased significantly in the Pb exposed rats at $\operatorname{PND} 21(p=0.04)$ but not at $\operatorname{PND} 30(p=0.18)$. The association between $\mathrm{BPbL}$ and vitamin $\mathrm{D}$ metabolites is shown in Figure 1. Regression analysis showed significant negative associations between $\mathrm{BPbL}$ and $25(\mathrm{OH}) \mathrm{D}$ in both PND21 and PND30 groups were found (PND21; $\beta=-0.64$, $R^{2}=0.47, p<0.0001$ and PND30; $\left.\beta=-0.78, R^{2}=0.25, p<0.01\right)$. BPbL was negatively associated with $1,25(\mathrm{OH})_{2} \mathrm{D}$ levels in the PND21 pups $\left(\beta=-0.02, R^{2}=0.22, p<0.05\right)$ but not in the PND30 pups $\left(\beta=-0.02, R^{2}=0.05, p>0.05\right)$.
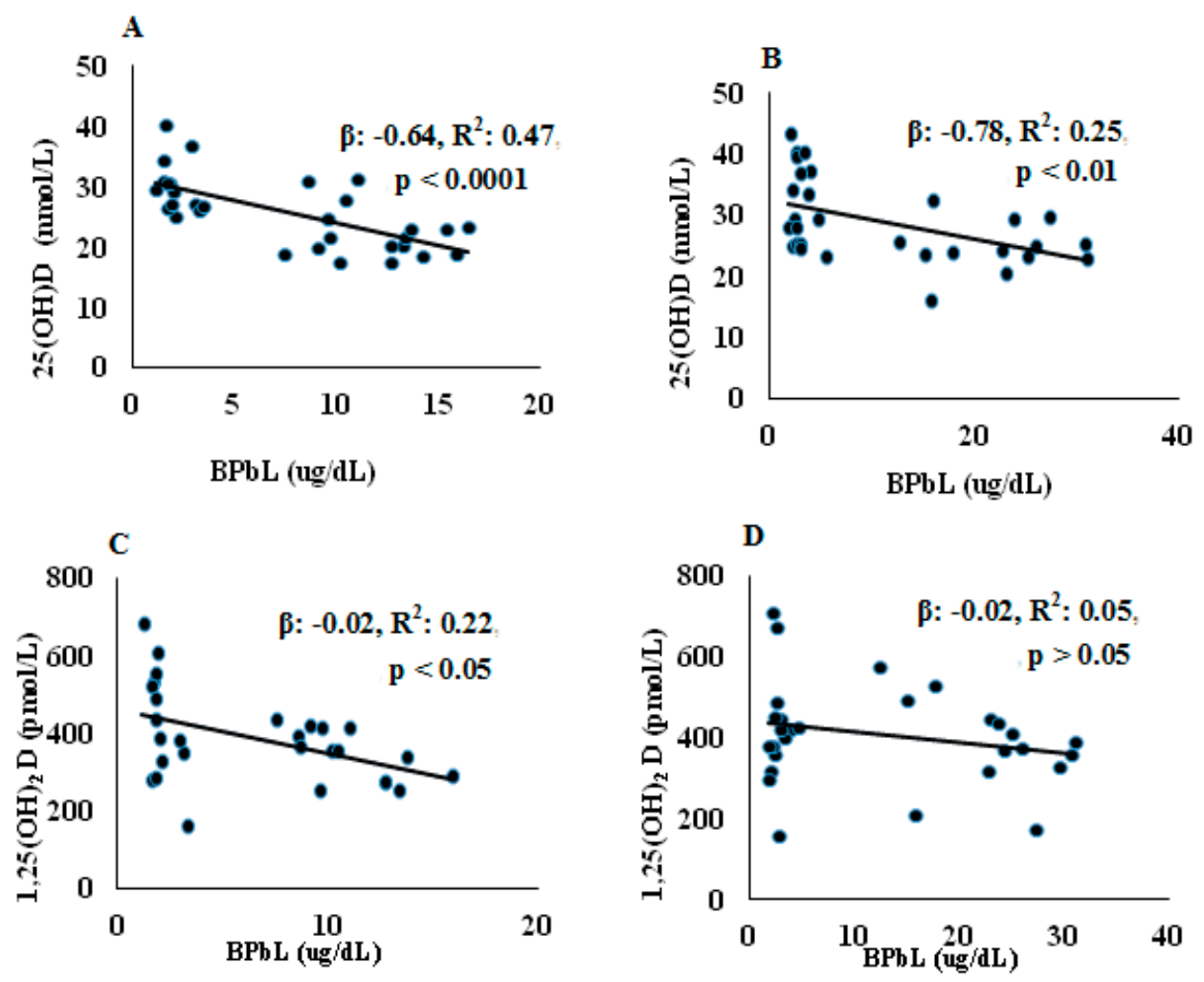

Figure 1. Association between $\mathrm{BPbL}$ and $\mathrm{VD}$ metabolites in control and $\mathrm{Pb}$-exposed Wistar rat pups. Linear regression analysis was conducted between $\mathrm{BPbL}(\mu \mathrm{g} / \mathrm{dL})$ and $(\mathrm{A}) 25(\mathrm{OH}) \mathrm{D}(\mathrm{nmol} / \mathrm{L})$ in PND21 rats $(n=39) ;(\mathbf{B}) 25(\mathrm{OH}) \mathrm{D}(\mathrm{nmol} / \mathrm{L})$ in PND30 rats $(n=36) ;(\mathbf{C}) 1,25(\mathrm{OH})_{2} \mathrm{D}(\mathrm{pmol} / \mathrm{L})$ in PND21 rats $(n=39) ;(\mathbf{D}) 1,25(\mathrm{OH})_{2} \mathrm{D}(\mathrm{pmol} / \mathrm{L})$ in PND30 rats $(n=36)$.

\subsection{Effects of Pb Exposure on 1- $\alpha$-Hydroxylase Expression and Distribution in Cerebrum and Kidney}

The expression of brain 1- $\alpha$-hydroxylase (CYP27B1) was not significantly affected by Pb-exposure either at PND21 or PND30 (Figure 2). CYP27B1 was visualized in the cerebral cortex in both control and $\mathrm{Pb}$-exposed pups at both age groups (Figure 3 ). In the kidney, Pb exposure resulted in a significant decrease of CYP27B1 level (by 22\%) in the PND21 group ( $p=0.01$ ), whereas in the PND30 group, $\mathrm{Pb}$ exposure had no effect on the expression of renal CYP27B1 (Figure 4). The immunohistochemistry of kidney tissue (Figure 5) showed that the expression of CYP27B1was more pronounced in the proximal convoluted tubules and was largely cytoplasmic. Parallel to the Western blot results, fewer CYP27B1 immunoreactive cells were visualized by immunohistochemistry in the kidneys of PND21 pups but not in the PND30 Pb-exposed pups as compared to their respective controls. 

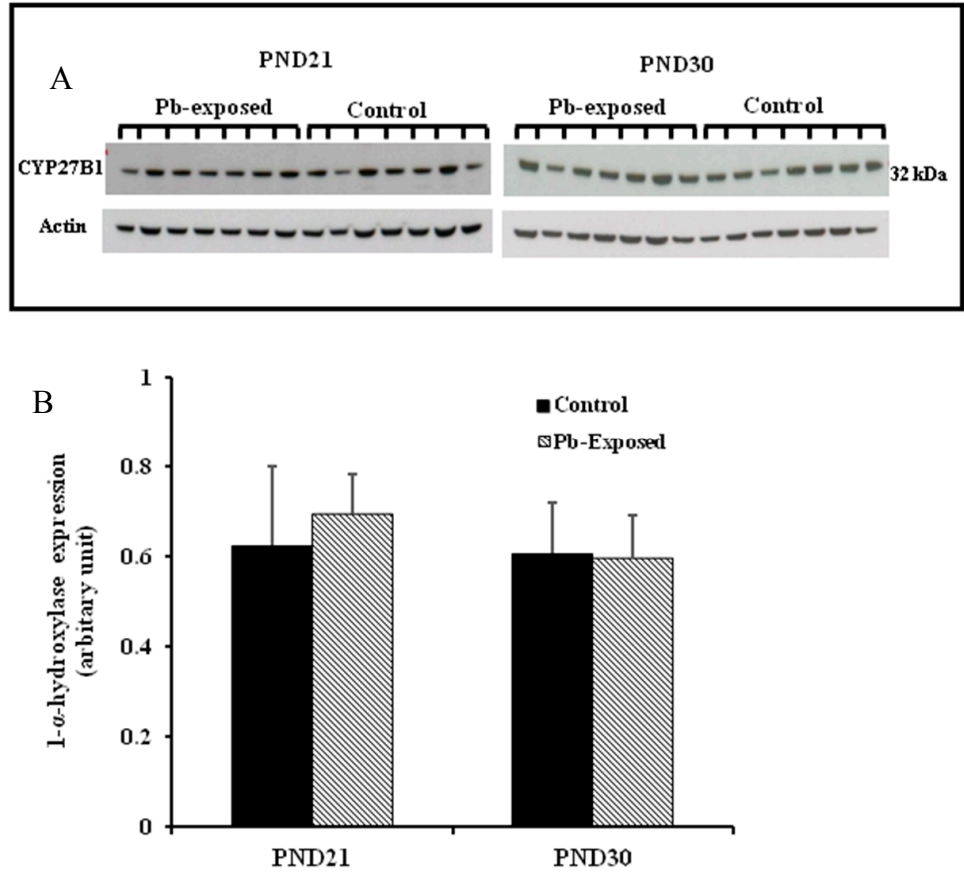

Figure 2. Effect of $\mathrm{Pb}$ exposure on the expression of 1- $\alpha$-hydroxylase in the cerebral hemispheres of Wistar rat pups. (A) Western blot analysis of cerebral tissue of control and Pb-exposed rats with 1- $\alpha$-hydroxylase antibody at PND21 and PND30: $20 \mu \mathrm{g}$ of the lysate was resolved on 10\% SDS-PAGE and immunoblotted with antibody to 1- $\alpha$-hydroxylase (CYP27B1). For loading control, the same membranes were stripped and re-probed with anti-actin antibody; (B) Quantification of Western blot bands at $32 \mathrm{kDa}$ for 1- $\alpha$-hydroxylase on the blots (shown in A): Blots (both CYP27B1 and actin) were scanned and the band densities quantified with Syngene gene tool software. Signal for this enzyme was normalized to signal for $\beta$-actin (for a loading control). Data are presented as Mean $\pm \operatorname{SD}(n=7)$.

Control
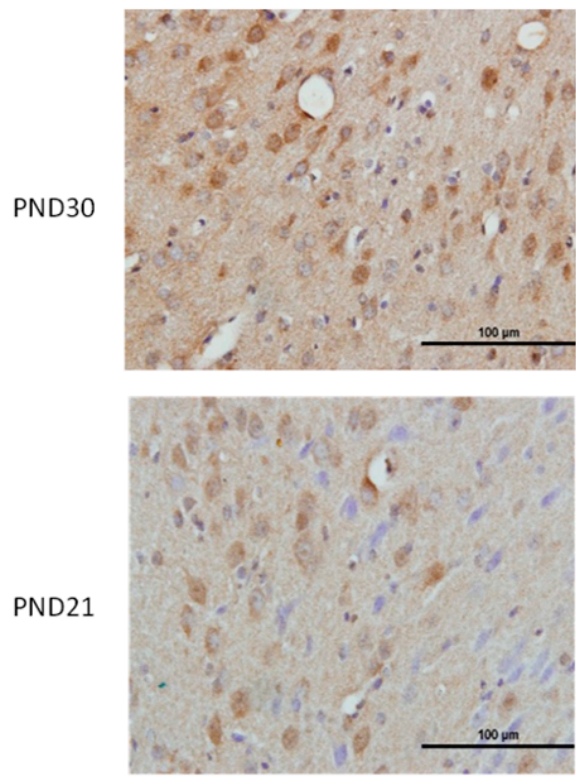

$\mathrm{Pb}$-exposed
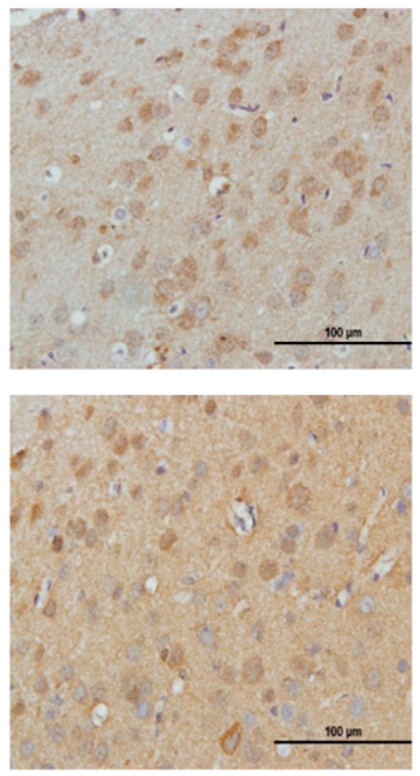

Figure 3. Immunohistochemistry photomicrographs showing the effects of $\mathrm{Pb}$ exposure on the expression of 1- $\alpha$-hydroxylase in cerebral cortex of PND21 and PND30 rats. Sections $(n=3)$ counterstained with Mayer's hematoxylin were photographed with oil immersion lens. 

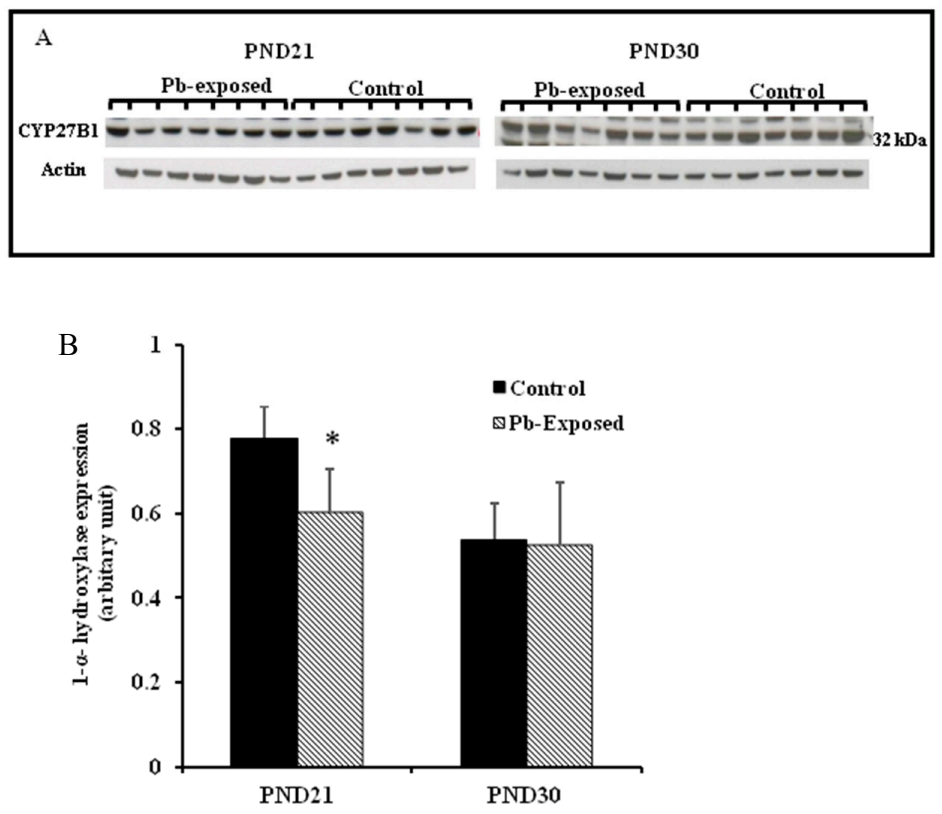

Figure 4. Effect of $\mathrm{Pb}$ exposure on the expression of 1- $\alpha$-hydroxylase in the kidney of Wistar rat pups: (A) Western blot analysis of kidney tissue of control and $\mathrm{Pb}$-exposed rats with 1- $\alpha$-hydroxylase (CYP27B1) antibody at PND21 and PND30: $20 \mu \mathrm{g}$ of kidney lysate was resolved on 10\% SDS-PAGE and immunoblotted with antibody to CYP27B1. For loading control, the same membranes were stripped and re-probed with anti-actin antibody; (B) Quantification of Western blot bands at $32 \mathrm{kDa}$ for CYP27B1 on the blots (shown in A): Blots (both CYP27B1 and actin) were scanned and the band densities quantified with Syngene gene tool software. Signal for this enzyme was normalized to signal for $\beta$-actin (for a loading control). Data are presented as Mean $\pm \operatorname{SD}(n=7)$. * Significantly different from control $(p<0.05)$.

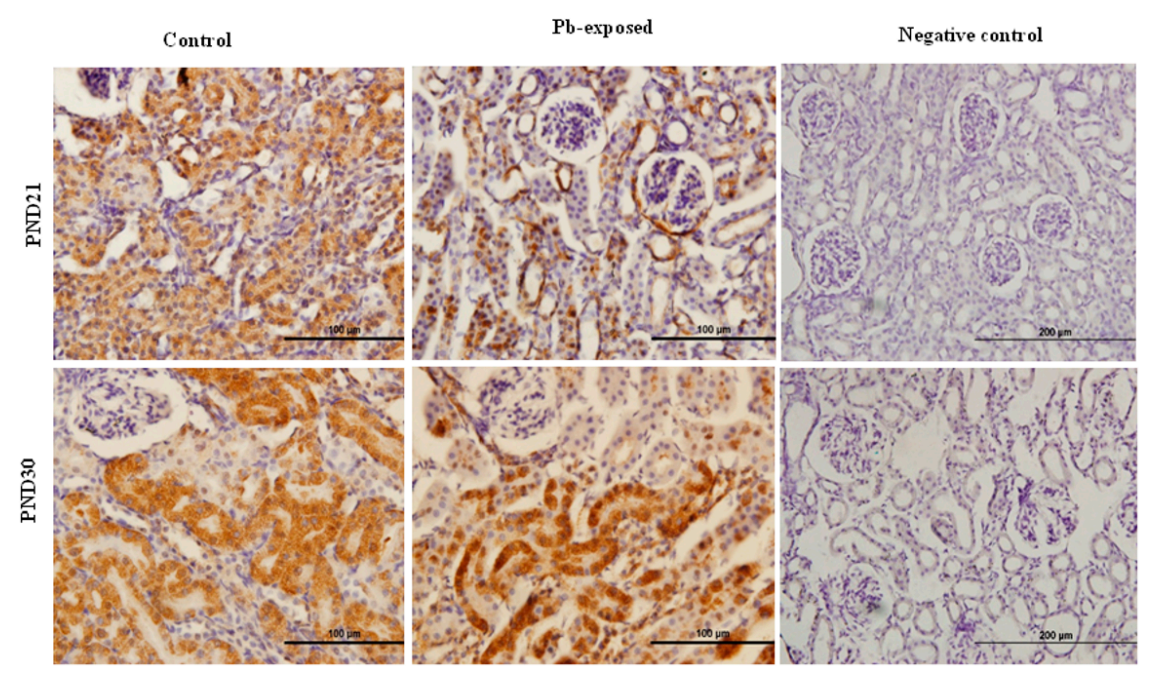

Figure 5. Immunohistochemistry photomicrographs showing the effects of $\mathrm{Pb}$ exposure on the expression of 1- $\alpha$-hydroxylase in kidney of both control and Pb-exposed at PND21 and PND30 rats. Sections $(n=3)$ were counterstained with Mayer's hematoxylin.

\subsection{Effects of Pb Exposure on 25-Hydroxylase Expression in Liver}

The expression of hepatic 25-hydroxylase (CYP27A1) in response to Pb exposure was significantly reduced $(21 \%)$ in PND21 rat pups $(p=0.04)$, whereas, in PND30, it was significantly increased by 33\% 
$(p=0.02)$ (Figure 6). The immunohistochemistry of liver tissue showed that CYP27A1 was expressed across the organ in both control and Pb-exposed rats at both PND21 and PND30 (Figure 7).

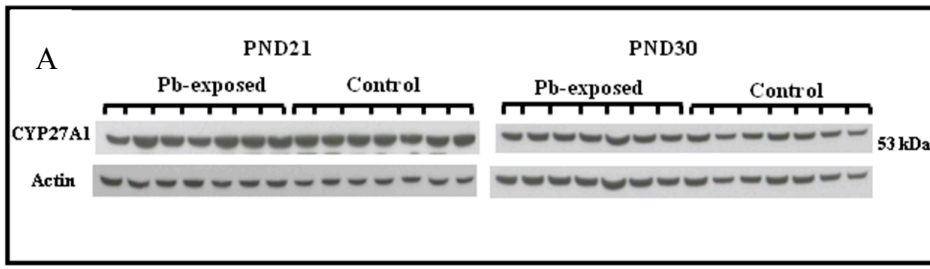

B

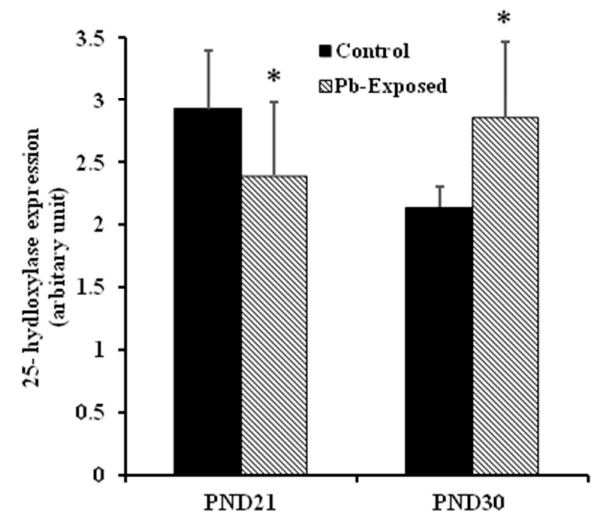

Figure 6. Effect of $\mathrm{Pb}$ exposure on the expression of 25-hydroxylase in the liver of Wistar rat pups: (A) Western blot analysis of liver tissue of control and Pb-exposed rats with 25-hydroxylase (CYP27A1) antibody at PND21 and PND30: $20 \mu \mathrm{g}$ of liver lysate was resolved on 10\% SDS-PAGE and immunoblotted with antibody to CYP27A1. For loading control, the same membranes were stripped and re-probed with anti-actin antibody; (B) Quantification of Western blot bands at $53 \mathrm{kDa}$ for 25-hydroxylase on the blots (shown in A): Blots (both CYP27A1 and actin) were scanned and the band densities quantified with Syngene gene tool software. Signal for this enzyme was normalized to signal for $\beta$-actin (loading control). Data are presented as Mean $\pm \operatorname{SD}(n=7)$. ${ }^{*}$ Significantly different from control $(p<0.05)$.

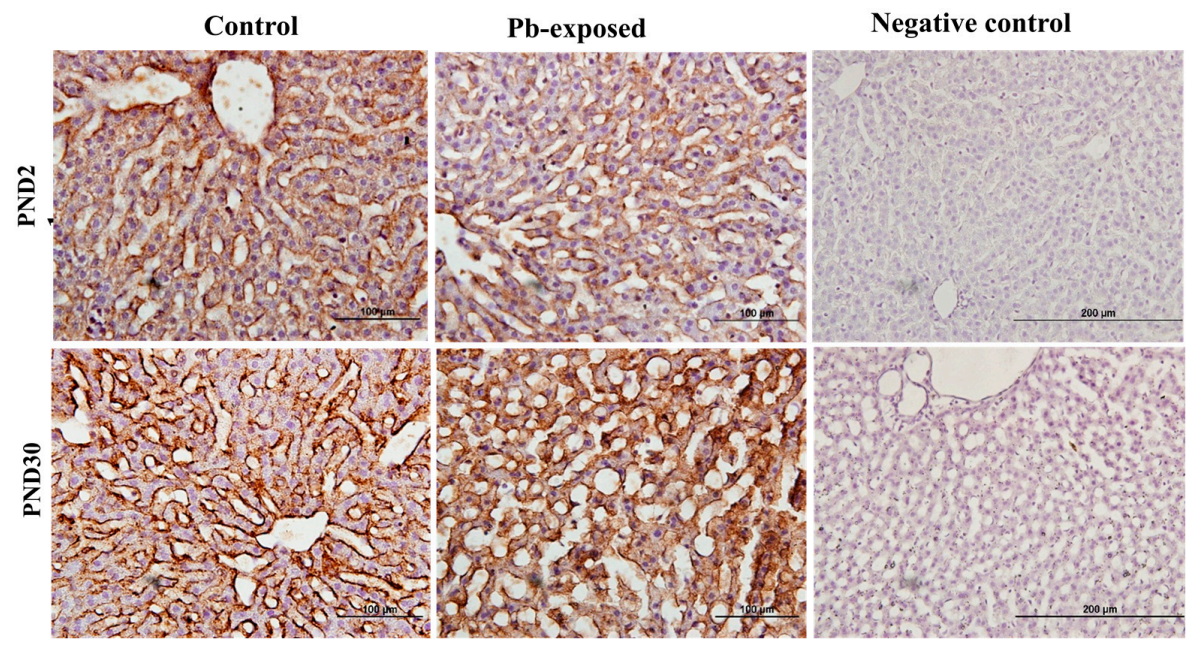

Figure 7. Immunohistochemistry photomicrographs showing the effect of $\mathrm{Pb}$ exposure on 25-hydroxylase expression in liver of both control and Pb-exposed rats at PND21 and PND30. Sections $(n=3)$ were counterstained with Mayer's hematoxylin. 


\subsection{Effects of $\mathrm{Pb}$ Exposure on VDR Expression in Cerebrum}

$\mathrm{Pb}$ exposure significantly increased VDR expression in the cerebral hemispheres by $20 \%$ at PND21 $(p=0.03)$ and by $29 \%$ at PND30 ( $p=0.02)$ (Figure 8$)$. The immunohistochemistry of VDR in the $\mathrm{Pb}$-exposed rats was consistent with Western blot results. More neurons in the Pb-exposed rats were immunoreactive for VDR in comparison to their respective controls (Figures 9 and 10). The localization of VDR was restricted to the nucleus of brain cells and was observed in the cerebral cortex as well as the thalamus in both control and $\mathrm{Pb}$-exposed rats at both age groups.
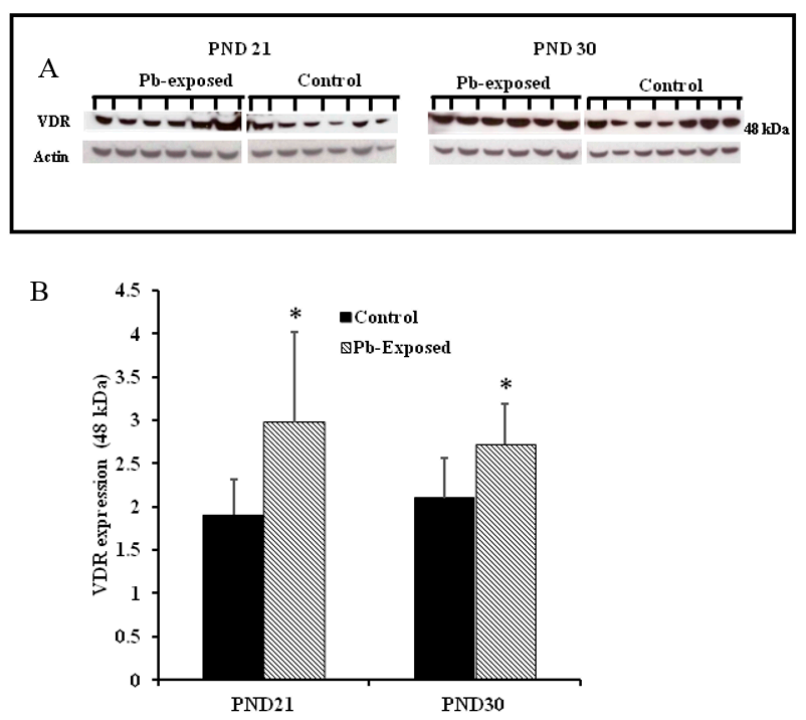

Figure 8. Effect of $\mathrm{Pb}$ exposure on VDR expression in the brain of Wistar rat pups: (A) Western blot analysis of brain tissue of control and Pb-exposed rats with VDR antibody at PND21 and PND30: $20 \mu \mathrm{g}$ of brain lysate was resolved on 10\% SDS-PAGE and immunoblotted with antibody to VDR. For loading control, the same membranes were stripped and re-probed with anti-actin antibody; (B) Quantification of Western blot bands at $48 \mathrm{kDa}$ for VDR on the blots (shown in A): Blots (both VDR and actin) were scanned and the band densities quantified with Syngene gene tool software. Signal for VDR was normalized to signal for $\beta$-actin (loading control). Data are presented as Mean $\pm \operatorname{SD}(n=7)$. * Significantly different from control $(p<0.05)$.

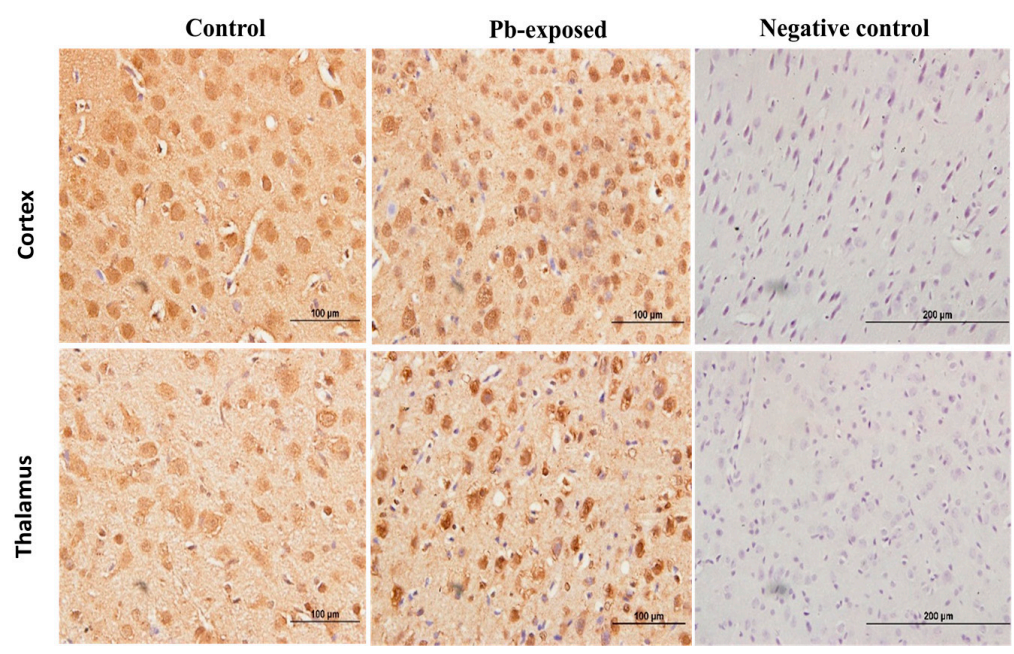

Figure 9. Immunohistochemistry photomicrographs showing the effect of $\mathrm{Pb}$ exposure on the expression of VDR in cerebrum of both control and Pb-exposed PND21 rats. Sections $(n=3)$ were counterstained with Mayer's hematoxylin. CR, cortex; TH, thalamus. 


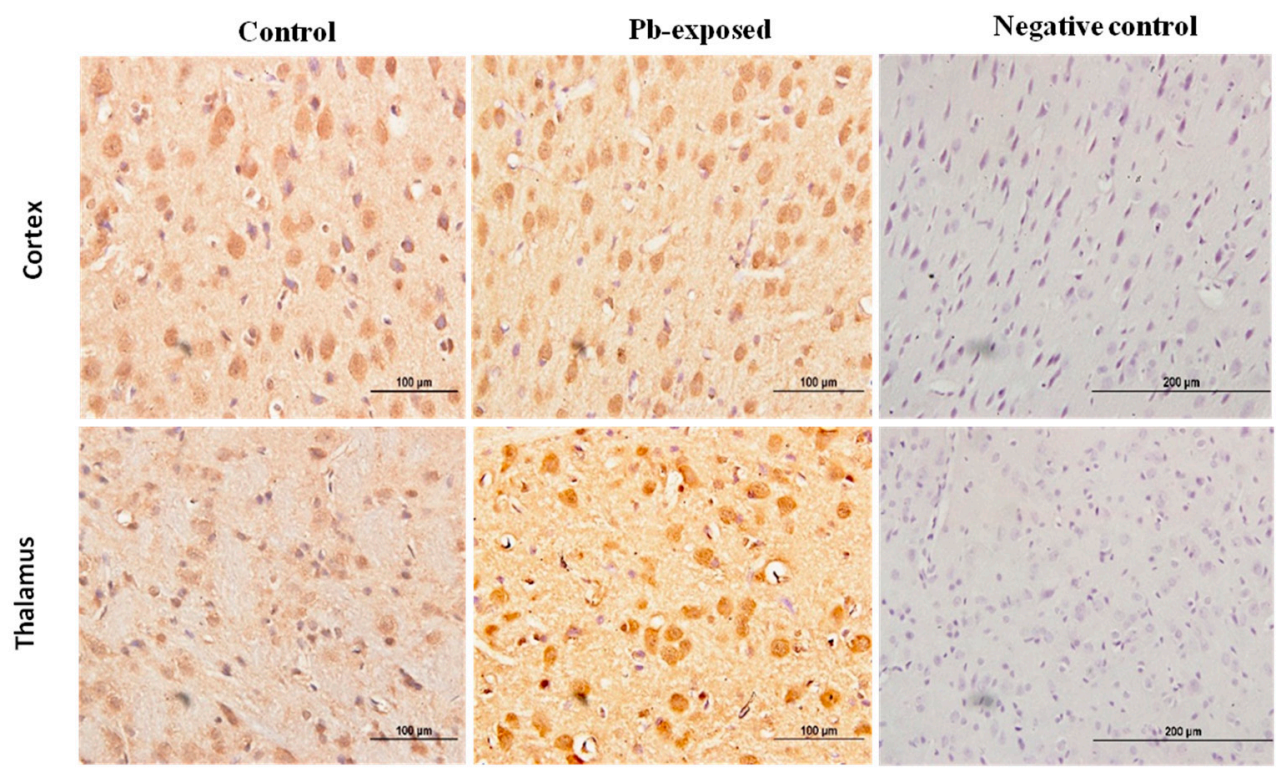

Figure 10. Immunohistochemistry photomicrographs showing the effect of $\mathrm{Pb}$ exposure on the expression of VDR in cerebrum of both control and Pb-exposed PND30 rats. Sections $(n=3)$ were counterstained with Mayer's hematoxylin. CR, cortex; TH, thalamus.

\section{Discussion}

The present study aimed to investigate whether $\mathrm{Pb}$ interferes with vitamin $\mathrm{D}$ metabolism by affecting the expression of its metabolizing enzymes (25-hydroxylase and 1- $\alpha$-hydroxylase) and VDR in Wistar rats. To our knowledge, this is the first experimental study that examined the effects of $\mathrm{Pb}$ on serum vitamin D concentrations (both $25(\mathrm{OH}) \mathrm{D}$ and $1,25(\mathrm{OH})_{2} \mathrm{D}$ ), expression of 25 -hydroxylase and 1 - $\alpha$-hydroxylase and VDR in organs that are involved in vitamin D metabolism; both quantitatively and qualitatively employing Western blotting and immunohistochemistry.

\subsection{Model Appropriateness and $\mathrm{Pb}$ Exposure Protocol}

The daily oral administration of $\mathrm{Pb}$ in drinking water mimics the environmental $\mathrm{Pb}$ exposure to which children are generally exposed. Measuring $\mathrm{BPbL}$ is the most sensitive biomarker for reflecting current exposure to $\mathrm{Pb}$. We used Wistar rat model since it has been extensively used to detect the $\mathrm{Pb}$-induced toxicity in brain [13,33-35], liver [36-38] and kidneys [39-41]. Our Pb exposure protocol did not significantly affect total body weight or organ weights and these results correspond with the findings from previous studies in rats [35,42-44]. The $\mathrm{Pb}$ exposure protocol used in the present study significantly increased BPbLs at both PND21 and PND30 in the Pb exposed animals compared to their corresponding controls. These results are comparable with previously reported data using similar $\mathrm{Pb}$ exposure protocol $(0.2 \% \mathrm{~Pb}$ acetate) $[13,34,35,38]$.

\subsection{Effects of Pb on Serum VD Metabolism}

Rat pups were fed normal EURodent Diet 14\% (Cat. No. 5LF2, LabDiet, St. Louis, MO, USA) which contained $1.0 \mathrm{IU}$ of vitamin $\mathrm{D}_{3}$ per gram of food. The estimated average food intake for a PND21 rat is $15 \mathrm{~g} /$ day, whereas, it is $30 \mathrm{~g} /$ day for a PND30 rat [45]. Based on this estimated food intake, the average intake was $15 \mathrm{IU} /$ day and $30 \mathrm{IU} /$ day of vitamin $\mathrm{D}_{3}$ for the PND21 and PND30 pups, respectively. Although the actual food intake was not measured in this study, it is assumed that the food intake of control and $\mathrm{Pb}$ exposed rats was similar, as no weight changes were observed. Therefore, it could be inferred that the apparent difference in serum vitamin $\mathrm{D}$ concentrations between control and $\mathrm{Pb}$-exposed rats was not due to the difference in vitamin $\mathrm{D}$ intake. Serum 25(OH)D concentrations in the control pups (Table 3) are within the normal range of rat of this age group [46,47]. Similarly, serum 
$1,25(\mathrm{OH})_{2} \mathrm{D}$ in the control pups were comparable with previously reported levels of this metabolite in control rats with similar vitamin D intake [45-48], indicating that our control pups were vitamin D sufficient. Furthermore, the lack of significant differences in the concentrations of $25(\mathrm{OH}) \mathrm{D}$ and $1,25(\mathrm{OH})_{2} \mathrm{D}$ between control pups of PND21 and PND30 and between Pb-exposed pups of PND21 and PND30 indicate that vitamin D levels during these developmental stages are age-independent. Interaction between vitamin $\mathrm{D}$ and serum concentration and/or dietary intake of essential divalent metal ions $(\mathrm{Ca}, \mathrm{Cu}, \mathrm{Fe}$ and $\mathrm{Zn})$ and toxic heavy metals $(\mathrm{Pb}$ and $\mathrm{Cd})$ has been reported [27]. In particular, the effect of high $\mathrm{BPbL}$ on these metal ions is well known. We have observed a 30-35\% reduction in the blood concentrations of $\mathrm{Cu}, \mathrm{Mn}$ and $\mathrm{Zn}$ in a similar protocol of $\mathrm{Pb}$ exposure in rats (unpublished); however, the levels of these metals were still within the physiological range. Furthermore, changes in the $25(\mathrm{OH}) \mathrm{D}$ concentration reported in this study are unlikely to affect Ca levels, as we have previously reported [32].

Our results showed that early postnatal $\mathrm{Pb}$ exposure of rats significantly decreased serum 25(OH)D levels at both PND21 and PND30 (Table 2). This was further confirmed with the strong negative association between BPbLs and serum 25(OH)D levels (PND21; $\beta=-0.64, R^{2}=0.47, p<0.0001$ and PND30; $\left.\beta=-0.78, R^{2}=0.25, p<0.01\right)$ in all rat pups of the same age $(n=31)$ irrespective of $\mathrm{Pb}$ exposure group. Few epidemiological studies have reported similar significant negative associations between $\mathrm{Pb}$ and serum 25(OH)D among women [49], Pb-exposed workers [20,21] and children [22,25]. Kersey et al. [50] have found negative but statistically insignificant, association between BPbls and serum 25(OH)D levels in healthy toddlers and children under 6 years of age. The 25(OH)D deficiency induced by $\mathrm{Pb}$ may indicate that $\mathrm{Pb}$ exposure interfered with hepatic 25-hydroxylase that is exclusively responsible for converting vitamin $\mathrm{D}$ into its major circulating form; $25(\mathrm{OH}) \mathrm{D}$. Furthermore, the effect of $\mathrm{Pb}$ on serum 25(OH)D levels in rats shown in the present study and in the reported studies in humans suggests that the effect of $\mathrm{Pb}$ on $25(\mathrm{OH}) \mathrm{D}$ is not species specific.

We showed that the expression of hepatic CYP27A1 was significantly decreased by $21 \%$ at PND21, whereas, at PND30 it was significantly increased by $33 \%$. These results do not parallel serum $25(\mathrm{OH}) \mathrm{D}$ changes that we observed. This apparent discrepancy in the effect of $\mathrm{Pb}$ on the expression of CYP27A1 in the liver suggest that $\mathrm{Pb}$-induced effects on liver are dependent on the developmental stage of the animal. The significant increase in CYP27A1 at PND30 may also be a compensatory mechanism for the decrease in serum 25(OH)D levels. The increased level of CYP27A1 but the decreased level of $25(\mathrm{OH}) \mathrm{D}$ may also suggest that although the synthesis of the enzyme is increased in response to the low level of circulating $25(\mathrm{OH}) \mathrm{D}$ level, its activity may be affected by $\mathrm{Pb}$. The enzyme quantity reflects both its synthesis and degradation and therefore higher levels of the enzyme expression do not necessarily imply that they are also highly active [51]. This apparent discordance in the PND30 rats may also be explained by the activation of 24-hydroxylase which is a catabolizing enzyme for both $25(\mathrm{OH}) \mathrm{D}$ and $1,25(\mathrm{OH})_{2} \mathrm{D}$. However, the expression of this enzyme was not measured in this study and this remains speculative. The immunohistochemistry results are parallel with the Western blot results as the photomicrographs of liver sections showed more pronounced expression of CYP27A1 in liver sections from PND30 rats compared to PND21 rats. Previous studies have shown that hepatic CYP27A1localized more in mitochondria and microsomes [52,53].

In addition, we found that $\mathrm{Pb}$ exposure significantly decreased serum $1,25(\mathrm{OH})_{2} \mathrm{D}$ levels only in the PND21 rats (Table 3). This effect was also confirmed by a negative association between BPbLs and serum $1,25(\mathrm{OH})_{2} \mathrm{D}$ levels among this age group $\left(\beta=-0.02, R^{2}=0.22, p<0.05, n=28\right)$. Similar reduction in serum $1,25(\mathrm{OH})_{2}$ D serum levels was reported by Smith et al., (1981) in Pb-exposed rats. In accordance with our results, previous studies have reported reduced serum $1,25(\mathrm{OH})_{2} \mathrm{D}$ levels in $\mathrm{Pb}$ exposed children [23,24] and female smelter workers [54]. They attributed this reduction to the inhibition of renal tubular CYP27B1 and therefore impaired renal biosynthesis of $1,25(\mathrm{OH})_{2} \mathrm{D}$. In contrast, other studies have shown an increase in $1,25(\mathrm{OH})_{2}$ D levels in Pb exposed rats, which has been explained as a compensatory mechanism to help normalize circulating calcium levels [55]. The observation that we did not find significant decrease in circulating $1,25(\mathrm{OH})_{2} \mathrm{D}$ levels in the Pb exposed rats at PND30 
despite significant decrease in serum $25(\mathrm{OH}) \mathrm{D}$ levels may also be explained by such mechanism. Fullmer [56] has argued that $\mathrm{Pb}$-induced effects on serum $1,25(\mathrm{OH})_{2} \mathrm{D}$ is Ca-dependent. He found that severe Ca deficiency was linked with low serum levels of $1,25(\mathrm{OH})_{2} \mathrm{D}$ and the levels were higher with less severe Ca deficiency.

Although CYP27B1 is mainly expressed in the kidney [3,52], it is also expressed in several other organs and tissues including the brain, activated cells of the immune system and the skin $[3,4,52,53,57]$. We selected kidney and the brain for the expression of this enzyme. The rationale is that kidney is the main site for the expression of this enzyme and it is involved in the calcemic effects of VD. $\mathrm{As} \mathrm{Pb}$ is neurotoxic and is known to impair learning and memory, we were interested to investigate if the $\mathrm{Pb}$-induced neurotoxicity might involve the dysregulation of brain CYP27B1. We found that the expression of CYP27B1 in renal tissue was significantly decreased by $22 \%$ only in PND21 Pb-exposed rats (Figure 5B), whereas it was not affected in PND30 rats. These results are perfectly in line with the serum $1,25(\mathrm{OH})_{2} \mathrm{D}$, which was significantly decreased in PND21 Pb-exposed rats but not in PND30 $\mathrm{Pb}$-exposed rats. In the brain tissue, on the other hand, the expression of this enzyme was not affected by $\mathrm{Pb}$ exposure at both age groups (Figure $5 \mathrm{~A}$ ). This apparent discrepancy in the effects of $\mathrm{Pb}$ in the kidney and brain CYP27B1 may suggest that these two enzymes are regulated by different mechanisms. The immunohistochemical localization of CYP27B1 was cytoplasmic and was present markedly in the proximal convoluted tubules in kidneys, as is well known from many previous studies $[3,52,53]$.

\subsection{Effects of $\mathrm{Pb}$ on $\mathrm{VDR}$}

VDRs are abundantly expressed in the brain. The expression of CYP27B, together with the expression of VDR in the brain, suggests that vitamin D is involved in brain development and function. Several studies including some from our laboratory have shown that VVD impairs learning and/or memory [32,58-60]. To explore the involvement of vitamin D signaling in Pb-induced neurotoxicity, we investigated the effect of $\mathrm{Pb}$ exposure on VDR expression in the brain. VDR has been shown to be widely distributed in rat and human brain and its pattern of distribution in the human brain was found to be similar to that of the rat $[3,4,57]$. Our results showed that $\mathrm{Pb}$ exposure caused significant increase of VDR expression at both age groups (Figure 5D). The biological actions of $1,25(\mathrm{OH})_{2} \mathrm{D}$ are mediated by its interaction with VDR [53]. This up-regulation of VDR expression in Pb-exposed rats at both PND21 and PND30 seems to be a response to the low circulating levels of $25(\mathrm{OH}) \mathrm{D}$, which was decreased by $\mathrm{Pb}$ exposure in both age groups. VDR level is also thought to be a determinant of cellular responsiveness to VD [61]. The VDR gene polymorphism has been found to increase or decrease human susceptibility to $\mathrm{Pb}$ poisoning [62] and different VDR genotypes have been associated with different $\mathrm{Pb}$-induced toxic effects [62-67]. Immunohistochemical results have shown that the VDR expression was restricted to the nucleus and localized mainly to brain cortex and thalamus (Figures 9 and 10) and these results are in agreement with previously reported data [4].

\subsection{Study Limitations}

There are few limitations in this study. First, a rat model was used in this study. Although the expressions of vitamin D metabolizing enzymes and VDR in rats are similar to that in humans, the effect of $\mathrm{Pb}$ on vitamin $\mathrm{D}$ metabolism may not be necessarily the same. As such, studies could not be conducted in humans due to ethical issues, using animal models was the only choice for conducting this study. Second, we did not study the male and female pups separately to investigate the gender-dependent effect of $\mathrm{Pb}$ exposure on vitamin $\mathrm{D}$ metabolism. Third, we studied the effects of $\mathrm{Pb}$ on the level of vitamin $\mathrm{D}$ activating enzyme in different tissue but did not study the effects of $\mathrm{Pb}$ on enzyme activity. Fourth, the catabolizing enzyme 24-hydroxlase is also involved in regulating serum concentrations of $25(\mathrm{OH}) \mathrm{D}$ and $1,25(\mathrm{OH})_{2} \mathrm{D}$ but the effect of $\mathrm{Pb}$ on this enzyme was not studied and thus should be included in future studies. Furthermore, this study did not address the mechanism(s) leading to these effects of $\mathrm{Pb}$ on the expression of vitamin $\mathrm{D}$ metabolizing enzymes and VDR. Further studies are warranted to investigate the physiological implications of these findings and 
the biochemical mechanism(s) by which $\mathrm{Pb}$ affects the expression of vitamin D metabolizing enzymes and VDR.

\section{Conclusions}

In conclusion, this study indicates that the influence of $\mathrm{Pb}$ on the expression of vitamin $\mathrm{D}$ activating enzymes is tissue-specific and depends on the developmental stage of the animal. The role of vitamin $\mathrm{D}$ in brain development and function is well-established. Our findings suggest a novel mechanism of $\mathrm{Pb}$-induced neurotoxicity. Based on our findings, we propose that $\mathrm{Pb}$-induced reduction in serum $25(\mathrm{OH}) \mathrm{D}$ is involved in $\mathrm{Pb}$-induced impairment of learning and memory. Further research, with properly designed experimental studies, is needed to test this hypothesis. In addition, further research is needed to elucidate the biochemical mechanism/(s) of these effects on the expression of CYP27A1 in liver and CYP27B in kidney and their physiological relevance by studying the activity of these enzymes. Furthermore, the mechanism by which $\mathrm{Pb}$ increases the expression of VDR and the implications of this increased expression of VDR in brain development and function need to be investigated in future research.

Acknowledgments: The authors acknowledge the excellent technical assistance of Sauzinha Fernandes, Sinu Joe and Saju Jacob. The support and cooperation of the staff and management of the United Genetics Laboratory, Kuwait; and the Trace Metal Laboratory, Kuwait Institute for Scientific Research is also acknowledged. This work was supported and funded by Kuwait University Research Project No. YW01/14 and the graduate student research grant from the College of Graduate Studies, Kuwait University.

Author Contributions: A.R. and K.M.K. designed research; A.A.A.-A. and K.M.K. conducted research; A.A.A.-A. and A.R. analyzed data and wrote the manuscript. A.R. supervised the project and had primary responsibility for final content. All authors read and approved the final manuscript.

Conflicts of Interest: The authors declare no conflict of interest.

\begin{tabular}{ll}
\multicolumn{2}{l}{ Abbreviations } \\
$\mathrm{Pb}$ & lead \\
$\mathrm{VDD}$ & vitamin D deficiency \\
$25(\mathrm{OH}) \mathrm{D}$ & 25-Hydroxyvitamin D \\
$1,25(\mathrm{OH})_{2} \mathrm{D}$ & 1,25-Dihydroxyvitamin D \\
$\mathrm{VDR}$ & Vitamin D receptor \\
$\mathrm{CYP} 27 \mathrm{~A} 1$ & 25-Hydroxylase \\
$\mathrm{CYP} 27 \mathrm{~B} 1$ & 1 $\alpha$-Hydroxylase \\
$\mathrm{PTH}$ & Parathyroid hormone \\
$\mathrm{PND}$ & Postnatal day \\
$\mathrm{BPbL}$ & Blood lead level \\
LC-MS/MS & Liquid chromatography-tandem mass spectrometry \\
ICP-OES & Inductively coupled plasma-optical emission \\
& spectrometer
\end{tabular}

\section{References}

1. DeLuca, H. Overview of general physiologic features and functions of vitamin D. Am. J. Clin. Nutr. 2004, 80, 1689S-1696S. [CrossRef] [PubMed]

2. DeLuca, G.; Kimball, S.; Kolasinski, J.; Ramagopalan, S.; Ebers, G. Review: The role of vitamin D in nervous system health and disease. Neuropathol. Appl. Neurobiol. 2013, 39, 458-484. [CrossRef] [PubMed]

3. Eyles, D.; Burne, T.; McGrath, J. Vitamin D, effects on brain development, adult brain function and the links between low levels of vitamin D and neuropsychiatric disease. Front. Neuroendocrinol. 2013, 34, 47-64. [CrossRef] [PubMed]

4. Eyles, D.; Smith, S.; Kinobe, R.; Hewison, M.; McGrath, J. Distribution of the Vitamin D receptor and $1 \alpha$-hydroxylase in human brain. J. Chem. Neuroanat. 2005, 29, 21-30. [CrossRef] [PubMed] 
5. Buell, J.; Scott, T.; Dawson-Hughes, B.; Dallal, G.; Rosenberg, I.; Folstein, M.; Tucker, K. Vitamin D is associated with cognitive function in elders receiving home health services. J. Gerontol. A Biol. Sci. Med. Sci. 2009, 64, 888-895. [CrossRef] [PubMed]

6. Lidsky, T.; Schneider, J. Lead neurotoxicity in children: Basic mechanisms and clinical correlates. Brain 2003, 126, 5-19. [CrossRef] [PubMed]

7. Liu, K.; Hao, J.; Zeng, Y.; Dai, F.; Gu, P. Neurotoxicity and biomarkers of lead exposure: A review. Chin. Med. Sci. J. 2013, 28, 178-188. [CrossRef]

8. Mason, L.; Harp, J.; Han, D. Pb Neurotoxicity: Neuropsychological Effects of Lead Toxicity. BioMed Res. Int. 2014, 2014, 1-8. [CrossRef] [PubMed]

9. Centers for Disease Control and Prevention. Lead. Workplace Safety \& Health Topics. CDC. 2013. Available online: http:/ / www.cdc.gov/niosh/topics/lead/ (accessed on 15 March 2017).

10. Kim, H.; Jang, T.; Chae, H.; Choi, W.; Ha, M.; Ye, B.; Kim, B.; Jeon, M.; Kim, S.; Hong, Y. Evaluation and management of lead exposure. AOEM 2015, 27, 1-9. [CrossRef] [PubMed]

11. Mithal, A.; Wahl, D.; Bonjour, J.; Burckhardt, P.; Dawson-Hughes, B.; Eisman, J.; El-Hajj Fuleihan, G.; Josse, R.G.; Lips, P.; Morales-Torres, J.; et al. Global vitamin D status and determinants of hypovitaminosis D. Osteoporos. Int. 2009, 20, 1807-1820. [CrossRef] [PubMed]

12. Van Schoor, N.; Lips, P. Worldwide vitamin D status. Best Pract. Res. Clin. Endocrinol. Metab. 2011, 25, 671-680. [CrossRef] [PubMed]

13. Rahman, A.; Al-Rashidi, H.; Khan, A. Association of Maternal Blood Lead Level during Pregnancy with Child Blood Lead Level and Pregnancy Outcome in Kuwait. Ecol. Food Nutr. 2012, 51, 40-57. [CrossRef] [PubMed]

14. Hilger, J.; Friedel, A.; Herr, R.; Rausch, T.; Roos, F.; Wahl, D.; Pierroz, D.; Weber, P.; Hoffmann, K. A systematic review of vitamin D status in populations worldwide. Br. J. Nutr. 2013, 111, 23-45. [CrossRef] [PubMed]

15. Palacios, C.; Gonzalez, L. Is vitamin D deficiency a major global public health problem? J. Steroid Biochem. Mol. Biol. 2014, 144, 138-145. [CrossRef] [PubMed]

16. Centers for Disease Control and Prevention. Lead $(\mathrm{Pb})$ Toxicity: What Are the U.S. Standards for Lead Levels? 2016. Available online: https:/ / www.atsdr.cdc.gov/csem/csem.asp?csem=34\&po=8 (accessed on 15 March 2017).

17. Tarragó, O.; Demers, R.; Becker, C.; Borak, J.; Cannella, J.; Goldstein, B.; Hall, A.; Jackson, R.; Rodnick, J.; Wheater, R.; et al. Lead Toxicity: Case Studies in Environmental Medicine (CSEM), 1st ed.; Agency for Toxic Substances and Disease Registry (ATSDR): Atlanta, GA, USA, 2012.

18. Budtz-Jørgensen, E.; Bellinger, D.; Lanphear, B.; Grandjean, P. An international pooled analysis for obtaining a benchmark dose for environmental lead exposure in children. Risk Anal. 2012, 33, 450-461. [CrossRef] [PubMed]

19. Nicholson, J.; Cleeton, M. Validation and Assessment of Pediatric Lead Screener Questions for Primary Prevention of Lead Exposure. Clin. Pediatr. 2016, 55, 129-136. [CrossRef] [PubMed]

20. Dongre, N.; Suryakar, A.; Patil, A.; Hundekari, I.; Devarnavadagi, B. Biochemical effects of lead exposure on battery manufacture workers with reference to blood pressure, calcium metabolism and bone mineral density. Indian J. Clin. Biochem. 2012, 28, 65-70. [CrossRef] [PubMed]

21. Mazumdar, I.; Goswami, K.; Ali, M. Status of serum calcium, vitamin D and parathyroid hormone and hematological indices among lead exposed jewelry workers in Dhaka, Bangladesh. Indian J. Clin. Biochem. 2016, 32, 110-116. [CrossRef] [PubMed]

22. Sorrell, M.; Rosen, J.; Roginsky, M. Interactions of lead, calcium, vitamin D and nutrition in lead-burdened children. Arch. Environ. Health 1977, 32, 160-164. [CrossRef] [PubMed]

23. Rosen, J.F.; Chesney, R.W.; Hamstra, A.; DeLuca, H.F.; Mahaffey, K.R. Reduction in 1,25-dihydroxyvitamin D in children with increased lead absorption. N. Engl. J. Med. 1980, 302, 1128-1131. [CrossRef] [PubMed]

24. Mahaffey, K.; Rosen, J.; Chesney, R.; Peeler, J.; Smith, C.; DeLuca, H. Association between age, blood lead concentration and serum 1,25-dihydroxycholecalciferol levels in children ${ }^{1-3}$. Am. J. Clin. Nutr. 1982, 35, 1327-1331. [CrossRef] [PubMed]

25. Chang, L.; Liu, X.; Shi, H.; Dai, W.; Wang, H.; Jiang, Y. Association of 25-hydroxyvitamin D with Hb and lead in children: A Chinese population-based study. Public Health Nutr. 2013, 17, 827-832. [CrossRef] [PubMed]

26. Smith, H.; DeLuca, C.; Tanaka, Y.; Mahaffey, K. Effect of lead ingestion on functions of vitamin D and its metabolites. J. Nutr. 1981, 111, 1321-1329. [CrossRef] [PubMed] 
27. Schwalfenberg, G.; Genuis, S. Vitamin D, essential minerals and toxic elements: Exploring interactions between nutrients and toxicants in clinical medicine. Sci. World J. 2015, 2015, 1-8. [CrossRef] [PubMed]

28. Fowler, B. Measuring Lead Exposure in Infants, Children and Other Sensitive Populations, 1st ed.; National Academy Press: Washington, DC, USA, 1993; p. 356.

29. Patrick, L. Lead Toxicity, a Review of the Literature. Part I: Exposure, Evaluation and Treatment. Altern. Med. Rev. 2006, 11, 1-22.

30. Monir, A.; Gundberg, C.; Yagerman, S.; van der Meulen, M.; Budell, W.; Boskey, A.; Dowd, T. The effect of lead on bone mineral properties from female adult C57/BL6 mice. Bone 2010, 47, 888-894. [CrossRef] [PubMed]

31. Anticona, C.; Sebastian, M. Anemia and malnutrition in indigenous children and adolescents of the Peruvian Amazon in a context of lead exposure: A cross-sectional study. Glob. Health Action 2014, 7, 1-8. [CrossRef] [PubMed]

32. Al-Harbi, A.N.; Khan, K.M.; Rahman, A. Developmental Vitamin D Deficiency Affects Spatial Learning in Wistar Rats. J. Nutr. 2017, 147, 1-11. [CrossRef] [PubMed]

33. Deveci, E. Ultrastructural effects of lead acetate on brain of rats. Toxicol. Ind. Health 2006, 22, 419-422. [CrossRef] [PubMed]

34. Rahman, A.; Khan, K.; Al-Khaledi, G.; Khan, I.; Al-Shemary, T. Over activation of hippocampal serine/threonine protein phosphatases PP1 and PP2A is involved in lead-induced deficits in learning and memory in young rats. Neurotoxicology 2012, 33, 370-383. [CrossRef] [PubMed]

35. Basha, C.; Reddy, R. Long-term changes in brain cholinergic system and behavior in rats following gestational exposure to lead: Protective effect of calcium supplement. Interdiscip. Toxicol. 2015, 8, 158-168. [CrossRef] [PubMed]

36. Nehru, B.; Kaushal, S. Alterations in the hepatic enzymes following experimental lead poisoning. Biol. Trace Elem. Res. 1993, 38, 27-34. [CrossRef] [PubMed]

37. Mujaibel, L.; Kilarkaje, N. Mitogen-activated protein kinase signaling and its association with oxidative stress and apoptosis in lead-exposed hepatocytes. Environ. Toxicol. 2013, 30, 513-529. [CrossRef] [PubMed]

38. Haouas, Z.; Sallem, A.; Zidi, I.; Hichri, H.; Mzali, I.; Mehdi, M. Hepatotoxic Effects of Lead Acetate in Rats: Histopathological and Cytotoxic Studies. J. Cytol. Histol. 2014, 5, 256-261.

39. Nolan, C.; Shaikh, Z. Lead nephrotoxicity and associated disorders: Biochemical mechanisms. Toxicology 1992, 73, 127-146. [CrossRef]

40. Ghorbe, F.; Boujelbene, M.; Makni-Ayadi, F.; Guermazi, F.; Kammoun, A.; Murat, J.; Croute, F.; Soleilhavoup, J.; El-Feki, A. Effect of Chronic Lead Exposure on Kidney Function in Male and Female Rats: Determination of a Lead Exposure Biomarker. Arch. Physiol. Biochem. 2001, 109, 457-463. [CrossRef] [PubMed]

41. Odigie, I.P.; Ladipo, C.O.; Ettarh, R.R.; Izegbu, M.C. Effect of chronic exposure to low levels of lead on renal function and renal ultrastructure in SD rats. Niger. J. Physiol. Sci. 2004, 19, 27-32. [CrossRef]

42. Zhu, Z.; Yang, R.; Dong, G.; Zhao, Z. Study on the neurotoxic effects of low-level lead exposure in rats. J. Zhejiang Univ. Sci. B 2005, 6, 686-692. [CrossRef] [PubMed]

43. Feng, C.; Gu, J.; Zhou, F.; Li, J.; Zhu, G.; Guan, L.; Liu, H.; Du, G.; Feng, J.; Liu, D.; et al. The effect of lead exposure on expression of SIRT1 in the rat hippocampus. Environ. Toxicol. Pharmacol. 2016, 44, 84-92. [CrossRef] [PubMed]

44. Guariglia, S.; Stansfield, K.; McGlothan, J.; Guilarte, T. Chronic early life lead $\left(\mathrm{Pb}^{2+}\right)$ exposure alters presynaptic vesicle pools in hippocampal synapses. BMC Pharmacol. Toxicol. 2016, 17, 56-63. [CrossRef] [PubMed]

45. Keeney, J.; Förster, S.; Sultana, R.; Brewer, L.; Latimer, C.; Cai, J.; Klein, J.; Porter, N.; Butterfield, D. Dietary vitamin $\mathrm{D}$ deficiency in rats from middle to old age leads to elevated tyrosine nitration and proteomics changes in levels of key proteins in brain: Implications for low vitamin D-dependent age-related cognitive decline. Free Radic. Biol. Med. 2013, 65, 324-334. [CrossRef] [PubMed]

46. Trechsel, U.; Taylor, C.; Eisman, J.; Bonjour, J.; Fleisch, H. Plasma Levels of Vitamin D Metabolites in Diphosphonate Treated Rats. Clin. Sci. 1981, 61, 471-476. [CrossRef] [PubMed] 
47. Stavenuiter, A.; Arcidiacono, M.; Ferrantelli, E.; Keuning, E.; Vila Cuenca, M.; ter Wee, P.; Beelen, R.; Vervloet, M.; Dusso, A. A Novel Rat Model of Vitamin D Deficiency: Safe and Rapid Induction of Vitamin D and Calcitriol Deficiency without Hyperparathyroidism. BioMed Res. Int. 2015, 2015, 1-5. [CrossRef] [PubMed]

48. Sonneveld, R.; Hoenderop, J.; Stavenuiter, A.; Ferrantelli, E.; Baltissen, M.; Dijkman, H.; Florquin, S.; Rops, A.; Wetzels, J.; Berden, J.; et al. 1,25-Vitamin D3 Deficiency Induces Albuminuria. Am. J. Pathol. 2016, 186, 794-804. [CrossRef] [PubMed]

49. Jackson, L.; Cromer, B.; Panneerselvamm, A. Association between bone turnover, micronutrient intake and blood lead levels in pre- and postmenopausal women, NHANES 1999-2002. Environ. Health Perspect. 2010, 118, 1590-1596. [CrossRef] [PubMed]

50. Kersey, M.; Chi, M.; B Cutts, D. Anaemia, lead poisoning and vitamin D deficiency in low-income children: Do current screening recommendations match the burden of illness? Public Health Nutr. 2011, 14, 1424-1428. [CrossRef] [PubMed]

51. Murray, R.; Granner, D.; Mayes, P.; Rodwell, V. Harper's Illustrated Biochemistry, 26th ed.; McGraw-Hill: New York, NY, USA, 2003; p. 693.

52. Omdahl, J.; Morris, H.; May, B. Hydroxylase enzymes of the vitamin D pathway: Expression, Function and Regulation. Annu. Rev. Nutr. 2002, 22, 139-166. [CrossRef] [PubMed]

53. Bikle, D. Vitamin D metabolism, mechanism of action and clinical applications. Chem. Biol. 2014, 21, 319-329. [CrossRef] [PubMed]

54. Potula, V.; Henderson, A.; Kaye, W. Calcitropic Hormones, Bone Turnover and Lead Exposure among Female Smelter Workers. Arch. Environ. Occup. Health 2005, 60, 195-204. [CrossRef] [PubMed]

55. Kristal-Boneh, E.; Froom, P.; Yerushalmi, N.; Harari, G.; Ribak, J. Calcitropic hormones and occupational lead exposure. Am. J. Epidemiol. 1998, 147, 458-463. [CrossRef] [PubMed]

56. Fullmer, C. Lead-Calcium Interactions: Involvement of 1,25-Dihydroxyvitamin D. Environ. Res. 1997, 72, 45-55. [CrossRef] [PubMed]

57. Harms, L.; Burne, T.; Eyles, D.; McGrath, J. Vitamin D and the brain. Best Pract. Res. Clin. Endocrinol. Metab. 2011, 25, 657-669. [CrossRef] [PubMed]

58. Annweilera, C.; Montero-Odassob, M.; Llewellynd, D.; Richard-Devantoye, S.; Duquef, G.; Beaucheta, O. Meta-analysis of memory and executive dysfunctions in relation to vitamin D. J. Alzheimers Dis. 2013, 37, 147-171.

59. Latimer, C.; Brewer, L.; Searcy, J.; Chen, K.; Popovic, J.; Kraner, S.; Thibault, O.; Blalock, E.; Landfield, P.; Porter, N. Vitamin D prevents cognitive decline and enhances hippocampal synaptic function in aging rats. Proc. Natl. Acad. Sci. USA 2014, 111, E4359-E4366. [CrossRef] [PubMed]

60. Kuźma, E.; Soni, M.; Littlejohns, T.; Ranson, J.; Van Schoor, N.; Deeg, D.; Comijs, H.; Chaves, P.; Kestenbaum, B.; Kuller, L.; et al. Vitamin D and memory decline: Two population-based prospective studies. J. Alzheimers Dis. 2016, 50, 1099-1108. [CrossRef] [PubMed]

61. Slvsten, H.; Svendsen, M.; Fogh, K.; Kragballe, K. Upregulation of vitamin D receptor levels by 1,25(OH $)_{2}$ vitamin $\mathrm{D}_{3}$ in cultured human keratinocytes. Arch. Dermatol. Res. 1997, 289, 367-372.

62. Onalaja, A.; Claudio, L. Genetic susceptibility to lead poisoning. Environ. Health Perspect. 2000, 108, $23-28$. [CrossRef] [PubMed]

63. Pawlas, N.; Broberg, K.; Olewińska, E.; Prokopowicz, A.; Skerfving, S.; Pawlas, K. Modification by the genes ALAD and VDR of lead-induced cognitive effects in children. Neurotoxicology 2012, 33, 37-43. [CrossRef] [PubMed]

64. Pawlas, N.; Broberg, K.; Olewińska, E.; Kozłowska, A.; Skerfving, S.; Pawlas, K. Genetic modification of ALAD and VDR on lead-induced impairment of hearing in children. Environ. Toxicol. Pharmacol. 2015, 39, 1091-1098. [CrossRef] [PubMed]

65. Kaya-Akyüzlü, D.; Kayaalti, Z.; Söylemez, E.; Koca, D.; Söylemezoğlu, T. Does maternal VDR FokI single nucleotide polymorphism have an effect on lead levels of placenta, maternal and cord bloods? Placenta 2015, 36, 870-875. [CrossRef] [PubMed] 
66. Jhun, M.; Hu, H.; Schwartz, J.; Weisskopf, M.; Nie, L.; Sparrow, D.; Vokonas, P.; Park, S. Effect modification by vitamin $\mathrm{D}$ receptor genetic polymorphisms in the association between cumulative lead exposure and pulse pressure: A longitudinal study. Environ. Health 2015, 14, 5-13. [CrossRef] [PubMed]

67. Dong, Q.; Zhao, C.; Chen, F.; Ji, H.; Zhang, X.; Hao, H.; Li, Z.; Li, J.; Yuan, J. The relationship of vitamin D receptor gene and blood lead: A meta-analysis. Eur. PMC Plus 2016, 34, $206-209$. 